\title{
Impacts of Global Circulation Model (GCM) bias and WXGEN on Modeling Hydrologic Variables
}

\author{
Sangchul Lee ${ }^{1,2, *}$, Carlington W. Wallace ${ }^{3}$ (D) , Ali M. Sadeghi ${ }^{2}$, Gregory W. McCarty ${ }^{2}$ (D), \\ Honglin Zhong ${ }^{4}$ and In-Young Yeo ${ }^{4,5}$ (D) \\ 1 Department of Environmental Science and Technology, University of Maryland, \\ College Park, MD 20740, USA \\ 2 Hydrology and Remote Sensing Laboratory, USDA-ARS, Beltsville, MD 20705, USA; \\ Ali.Sadeghi@ars.usda.gov (A.M.S.); Greg.McCarty@ars.usda.gov (G.W.M.) \\ 3 Interstate Commission on the Potomac River Basin, Rockville, MD 20850, USA; cwwallac1@gmail.com \\ 4 Department of Geographical Sciences, University of Maryland, College Park, MD 20740, USA; \\ hzhong1@terpmail.umd.edu (H.Z.); in-young.yeo@newcastle.edu.au (I.-Y.Y.) \\ 5 School of Engineering, The University of Newcastle, Callaghan, NSW 2308, Australia \\ * Correspondence: sangchul.lee84@gmail.com; Tel.: +1-443-462-2927
}

Received: 30 April 2018; Accepted: 8 June 2018; Published: 12 June 2018

\begin{abstract}
A WXGEN weather generator is commonly used to generate daily climate data for Soil and Water Assessment Tool (SWAT) model when input climate data are not fully available. Of all input data for WXGEN, precipitation is critical due to its sensitivity to the number of wet days. Since global climate model (GCM) data tend to have excessive wet days, use of GCM precipitation data for WXGEN may cause errors in the estimation of climate variables and therefore SWAT predictions. To examine such impacts of GCM data, we prepared two climate data for SWAT using WXGEN with both the original GCM data with the excessive number of wet days (EGCM) and the processed GCM data with the reasonable number of wet days (RGCM). We then compared SWAT simulations from EGCM and RGCM. Results show that because of the excessive wet days in EGCM, solar radiation generated by WXGEN was underestimated, subsequently leading to $143 \mathrm{~mm}$ lower ET and $0.6-0.8 \mathrm{~m}^{3} / \mathrm{s}$ greater streamflow compared to the simulations from RGCM. Simulated crop biomass under EGCM was smaller than RGCM due to less solar radiation. Although use of WXGEN is increasing in projecting climate change impacts using SWAT, potential errors from the combination of WXGEN and GCM have not well investigated. Our findings clearly demonstrate that GCM bias (excessive wet days) leads WXGEN to generate inaccurate climate data, resulting in unreasonable SWAT predictions. Thus, GCM data should be carefully processed to use them for WXGEN.
\end{abstract}

Keywords: SWAT; WXGEN; GCM bias; excessive wet days

\section{Introduction}

Future climate conditions predicted by general circulation models (GCMs) have been widely used to predict potential changes [1]. Due to inherent uncertainty of GCM data, post-processing of GCM data (e.g., bias correction and downscaling) has been emphasized for their use with hydrologic and crop models [2,3]. The major bias of raw GCM data is excessive wet days [4,5]. Because GCMs estimate a representative value for each grid with a coarse spatial resolution [4,5], GCM tend to overestimate wet days. Accordingly, use of raw GCM data was known to decrease the accuracy of a hydrologic model and crop model, mainly due to biased precipitation [6,7].

The Soil and Water Assessment Tool (SWAT) model is one of widely used hydrologic models for projecting climate change impacts [8]. WXGEN, a SWAT built-in weather generator, has been 
used to prepare a complete set of climate data for model simulation for current as well as future climate conditions [9-14]. Due to high availability of precipitation and temperature data, these two climate variables are used as input data for WXGEN. Input precipitation is particularly critical for WXGEN because it is sensitive to the number of dry or wet days per a given month for calculating solar radiation [15]. For example, precipitation data with an increased number of wet days per a month cause WXGEN to underestimate solar radiation. Therefore, use of raw GCM characterized by excessive wet days for WXGEN can bring errors to climate variables generated from WXGEN, potentially affecting the accuracy of SWAT outputs. Notwithstanding post-processing (i.e., downscaled and bias-corrected), the GCM precipitation data were reported to overestimate wet days with $<10 \mathrm{~mm}$ precipitation $[16,17]$.

Poorly estimated solar radiation is capable of inaccurately representing crop growth pattern since solar radiation is a key component for estimating crop biomass. In addition, poorly estimated solar radiation could result in inaccurate potential evapotranspiration (PET). The Penman-Monteith method is one of the methods for estimating PET in SWAT and its use for climate change study is rapidly increasing because the method considers the impacts of elevated $\mathrm{CO}_{2}$ concentrations on PET [18]. Solar radiation is considered in the Penman-Monteith method, possibly leading to inaccurate PET if input solar radiation is not accurate. In turn, inaccurate PET might lead to unreasonable predictions of hydrologic variables by SWAT. Although use of a weather generator for climate change study is increasing, limited attention has been drawn to potential errors caused by use of GCM data as input data for WXGEN and their impacts on SWAT simulation results.

The goal of this study was to examine how GCM bias affects simulated hydrologic outputs of SWAT using climate variables generated by WXGEN. Model calibration and validation were performed during the baseline period (1999-2014). Post-processed GCM data (i.e., downscaled and bias-corrected) were obtained from World Climate Research Program's (WCRP's) Coupled Model Intercomparison Project5 (CMIP5) archive [19] to represent the future period (2083-2098). Since only precipitation and temperature are available from the WCRP, the rest of the climate data (e.g., humidity, wind speed, and solar radiation) were prepared using WXGEN. Since the GCM precipitation from WCRP is known to include excessive wet days $[16,17]$, use of WXGEN with those GCM data could demonstrate inaccurate model predictions caused by GCM bias (i.e., excessive wet days). We further corrected these GCM data to make precipitation data with the reasonable number of wet days. Comparison analysis of simulations (streamflow, nitrate loads, and crop biomass) from two precipitation datasets with a varying degree of wet days was performed.

\section{Materials and Methods}

\subsection{Study Area}

This study was performed on the Tuckahoe Creek Watershed (TCW, approximately $220.7 \mathrm{~km}^{2}$ ), a subbasin of the Choptank River watershed within the coastal plain of the Chesapeake Bay watershed (Figure 1). Numerous research activities have been conducted on the Choptank River watershed because it was identified as one of "impaired waters" under the Clean Water Act due to excessive sediment and nutrient loads [20] and it is a benchmark watershed for the US Department of Agriculture (USDA)-Natural Resources Conservation Service (NRCS) Conservation Effects Assessment Project (CEAP) [21]. The dominant land use is agriculture (54\%) and forest (33\%), followed by pasture $(8.4 \%)$, urban $(4.2 \%)$, and water body $(0.6 \%)$. Corn and soybean are mainly cultivated during summer seasons, and winter wheat is double cropped with soybean over winter seasons [22,23]. Soils are comprised of $56 \%$ well-drained (Hydrologic Soil Group (HSG) - A and B) and 44\% poorly drained soils (HSG-C and D). 


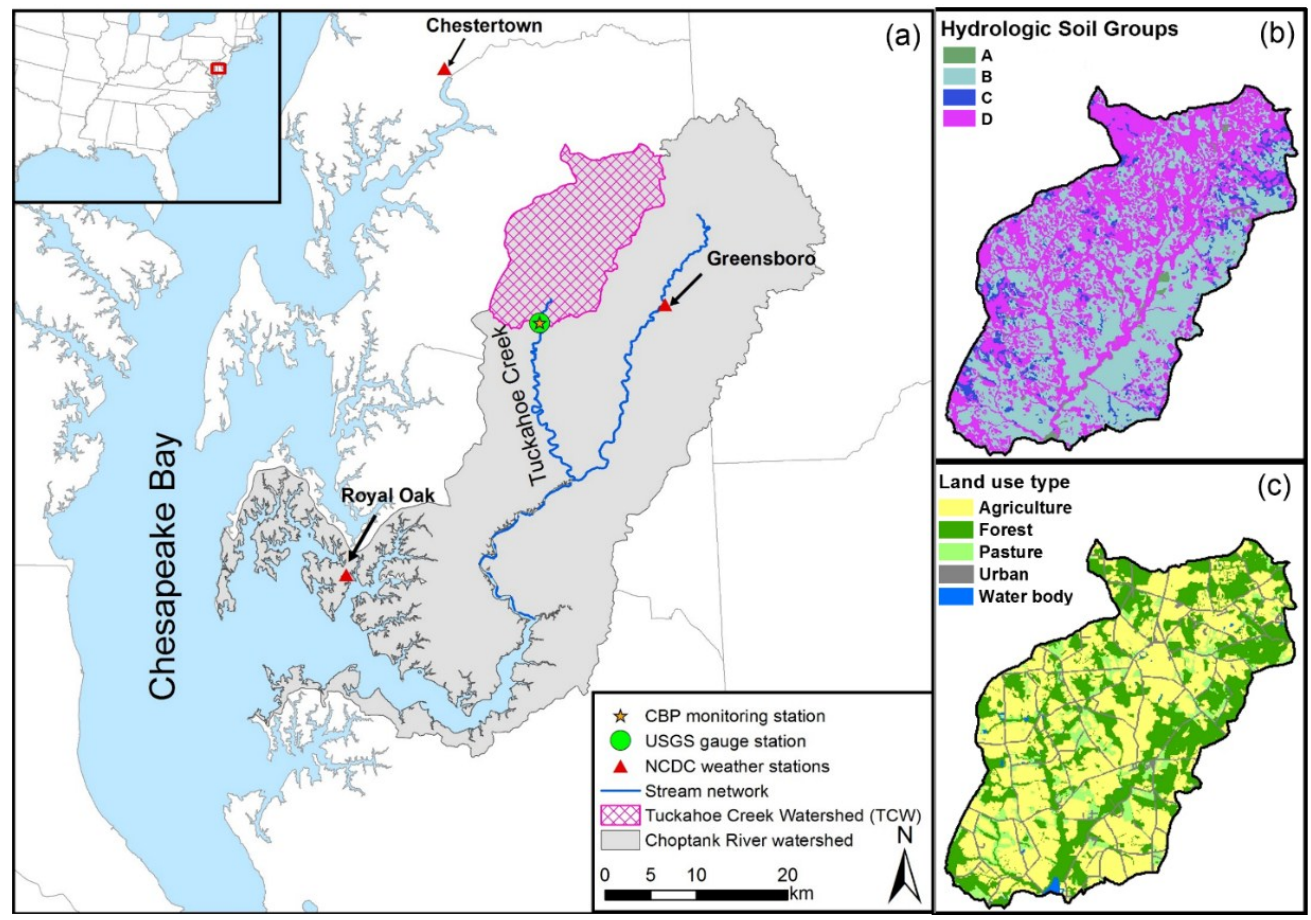

Figure 1. Location (a) soil (b) and land use (c) of the Tuckahoe Creek Watershed (adapted from [22]). HSGs are characterized as follows: A-well-drained soils with 7.6-11.4 mm/h water infiltration rate; $\mathrm{B}$-moderately well-drained soils with $3.8-7.6 \mathrm{~mm} / \mathrm{h}$; C-moderately poorly drained soils with 1.3-3.8 $\mathrm{mm} / \mathrm{h}$; and D-poorly drained soils with $0-1.3 \mathrm{~mm} / \mathrm{h}[18]$.

\subsection{Soil and Water Assessment Tool (SWAT)}

SWAT is a process-based water quality model developed to evaluate the impacts of land managements on hydrology, sediment, nutrient, and pesticide loads at the watershed scale. The model includes multiple components: weather, hydrology, nutrient cycle, plant growth, land management, routing process, in-stream process, etc. SWAT divides a watershed into sub-watersheds and further into Hydrologic Response Units (HRUs) determined from a unique combination of land use, soil, and slope within each sub-watershed. Water balance and nutrient cycles are simulated at individual HRUs and the simulated hydrologic variables are aggregated at the sub-watershed scale and then routed to the watershed outlet through the channel process. The water balance within each HRU is calculated as below:

$$
S W_{t}=S W_{0}+\sum_{i=1}^{t}\left(R_{\text {day }}-Q_{\text {surf }}-E_{a}-W_{\text {seep }}-Q_{g w}\right)
$$

where $S W_{t}$ is the final soil water content $\left(\mathrm{mm} \mathrm{H}_{2} \mathrm{O}\right), S W_{0}$ is the initial soil water content $\left(\mathrm{mm} \mathrm{H}_{2} \mathrm{O}\right)$, $\mathrm{t}$ is the time (days), $R_{\text {day }}$ is the amount of precipitation $\left(\mathrm{mm} \mathrm{H}_{2} \mathrm{O}\right), Q_{\text {surf }}$ is the amount of surface runoff day $\left(\mathrm{mm} \mathrm{H}_{2} \mathrm{O}\right), E_{a}$ is the amount of evapotranspiration $\left(\mathrm{mm} \mathrm{H}_{2} \mathrm{O}\right), W_{\text {seep }}$ is the amount of percolation and bypass flow existing the soil profile bottom $\left(\mathrm{mm} \mathrm{H}_{2} \mathrm{O}\right)$, and $Q_{g w}$ is the amount of groundwater flow $\left(\mathrm{mm} \mathrm{H}_{2} \mathrm{O}\right)$. SWAT provides three options for PET calculation: Penman-Monteith, Priestley-Taylor, and Hargreaves methods [18]. This study used the Monteith method because this method has been widely applied for investigating climate change impacts due to its capacity to calculate PET in response to $\mathrm{CO}_{2}$ concentration variation [24]. In the Penman-Monteith method, $\mathrm{CO}_{2}$ impact is considered by inclusion of the plant canopy resistance that is adjusted by $\mathrm{CO}_{2}$ concentration [18]. PET is calculated using multiple variables including canopy resistance, solar radiation, etc. Note that the equation 
for the Penman-Monteith method is available on the Equation (S1). Refer to Neitsch, et al. [18] for further details.

Plant growth is simulated using the concept of heat unit in SWAT [18]. At a daily time step, plant growth occurs when an average temperature exceeds the base temperature. Once a cumulative daily heat unit reaches the plant heat unit required for maturity, a plant halts its biomass growth as well as water and nutrient uptake. A daily heat unit is calculated by taking the difference between the average and base temperatures. When an average ambient temperature is equal to or lower than base temperature, a daily heat unit indicates " 0 " value. A biomass growth $(\Delta b i o)$ is calculated using radiation use efficiency (RUE) and solar radiation $\left(H_{\text {phosyn }}\right)$ as below:

$$
\Delta b i o=\text { RUE } \cdot H_{\text {phosyn }}
$$

\subsection{SWAT Input Data for the Baseline Period}

The baseline input data for the SWAT simulation are shown in Table 1. A light detection and ranging (LiDAR)-based digital elevation model (DEM) was provided by the Maryland (MD) Department of Natural Resources (DNR). A soil map originated from the USDA-NRCS Soil Survey Geographic Database (SSURGO). The land use map was developed using multiple geospatial data (Table 1). The placement of croplands and crop rotations for each cropland were prepared based on 2008-2012 data from the USDA's National Agriculture Statistics Service (NASS) Cropland Data Layer (CDL) [22]. Detailed land management schedules (e.g., planting and harvesting dates of crops and the amount, type, and application timings of fertilizers) were set based on communication with a local agricultural expert (Table 2) [22]. To calibrate crop biomass, corn and soybean yield data were downloaded from the USDA-National Agriculture Statistics Service (NASS). We used the county-level yield data from 2002 through 2010 for Caroline and Queen Anne's in Maryland, where the TCW is simulated, and state-level for specific years (2001, and 2011-2014) due to unavailability of county-level data.

Table 1. The list of input data (adapted from [22]).

\begin{tabular}{|c|c|c|c|}
\hline Data & Source & Description & Year \\
\hline DEM & MD-DNR & LiDAR-based 2-m resolution & 2006 \\
\hline \multirow{4}{*}{ Land use } & USDA-NASS & Cropland Data Layer (CDL) & 2008-2012 \\
\hline & MRLC & National Land Cover Database (NLCD) & 2006 \\
\hline & USDA-FSA-APFO & $\begin{array}{c}\text { National Agricultural Imagery Program digital } \\
\text { Orthophoto quad imagery }\end{array}$ & 1998 \\
\hline & US Census Bureau & TIGER road map & 2010 \\
\hline Soils & USDA-NRCS & Soil Survey Geographical Database (SSURGO) & 2012 \\
\hline Climate & NCDC & Daily precipitation and temperature & 1999-2014 \\
\hline Streamflow & USGS & Monthly streamflow & 2001-2014 \\
\hline Water quality & USGS and CBP & Daily grab nitrate samples & 2001-2014 \\
\hline Crop yield & USDA-NASS & Corn and soybean yield & 2001-2014 \\
\hline
\end{tabular}

We downloaded baseline daily precipitation and temperature for the period of 1999-2014 from the National Oceanic and Atmospheric Administration (NOAA) National Climate Data Center (NCDC) at Chestertown, Royal Oak, and Greensboro (USC00181750, USC00187806, and US1MDCL0009, respectively). Because observations of daily humidity, wind speed, and solar radiation are unavailable, those climate variables were prepared using WXGEN, SWAT built-in weather generator [18]. WXGEN calculates solar radiation and relative humidity based on a function of precipitation and temperature [15]. Two climatic variables are adjusted based on dry or wet conditions that are 
determined from the number of dry or wet days per given month, respectively [25]. WXGEN assumes that solar radiation tends to be lower on a wet day and the wet day radiation $\left(R_{W}\right)$ is the half of the dry day radiation $\left(R_{D}\right)$ :

$$
\begin{gathered}
R_{W}=0.5 \cdot R_{D} \\
R_{D}=\frac{R_{M} \cdot \text { days }_{T}}{5 \cdot \text { days }_{W}+\text { days }_{D}}
\end{gathered}
$$

where, $R_{W}$ is the average daily solar radiation for the month, days ${ }_{T}$ is the total number of days in the month, days ${ }_{W}$ and days ${ }_{D}$ are the total number of wet and dry days in the month, respectively.

Monthly streamflow was measured at the outlet of the TCW at the U.S. Geological Survey gauge station located on the Tuckahoe Creek near Ruthsburg (USGS\#01491500). We used the USGS LOAD ESTimator (LOADEST) [26] to prepare continuous monthly nitrate loads from nitrate grab sample data acquired from the Chesapeake Bay Program (CBP, TUK\#0181).

Table 2. The management schedules (adapted from Lee, et al. [22]).

\begin{tabular}{cccc}
\hline Crop & Planting & Fertilizer & Harvest \\
\hline Corn (after corn) & 30 April (no-till) & $\begin{array}{c}157 \mathrm{~kg} \mathrm{~N} / \text { ha of poultry manure on 20 April } \\
45 \mathrm{~kg} \mathrm{~N} / \text { ha of sidedress 30\% UAN on 7 June }\end{array}$ & 3 October \\
\hline $\begin{array}{c}\text { Corn (after Soybean and } \\
\text { Double crop soybean) }\end{array}$ & 30 April (no-till) & $\begin{array}{c}124 \mathrm{~kg} \mathrm{~N} / \text { ha of poultry manure on 20 April } \\
34 \mathrm{~kg} \mathrm{~N} / \text { ha of sidedress 30\% UAN on 7 June }\end{array}$ & 3 October \\
\hline Soybean & 20 May (no-till) & & 15 October \\
\hline $\begin{array}{c}\text { Double crop winter } \\
\text { wheat (Dbl WW) }\end{array}$ & 20 October & $\begin{array}{c}\text { 34 kg N/ha of sidedress 30\% UAN on 8 October } \\
67 \mathrm{~kg} \mathrm{~N} / \text { ha of sidedress 30\% UAN on 5 April }\end{array}$ & 27 June \\
\hline $\begin{array}{c}\text { Double crop soybean } \\
\text { (Dbl Soyb) }\end{array}$ & 29 June & & 1 November \\
\hline $\begin{array}{l}\text { Note: UAN stands for Urea-Ammonium Nitrate. The typical nitrogen content for poultry manure was set at } \\
2.8 \% \text { [13]. }\end{array}$ &
\end{tabular}

\subsection{The SWAT Input Data for the Future Period Indicated by GCM}

Except for input climate data, the baseline geospatial data were used for the future period (2083-2098). We downloaded the projections of daily precipitation and temperatures from the WCRP's CMIP5 [19]. Eight GCM data were downloaded separately for three representative concentration pathways (RCP 2.6, 4.5 and 8.5) indicating the radiative forcing level of $2.6-8.5 \mathrm{~W} / \mathrm{m}^{2}$ at the end of the century [27]. RCP 2.6, 4.5, and 8.5 were selected as representative "low", "medium", and "high" radiative forcing scenarios, respectively [27]. Note that we selected eight GCMs available for the three RCPs and the detailed description of eight GCMs is available in Table S1. To examine the impacts of excessive wet days, we prepared two GCM precipitation data. First, the original precipitation was directly used to depict the precipitation with excessive wet days. Although GCM dataset was preprocessed, the precipitation data were reported to include excessive wet days $[16,17]$. Then, we applied the delta change method into the original precipitation to set the same wet days as the baseline data. This dataset could depict the precipitation with the reasonable number of wet days. The delta change method has been widely used to correct biases in GCM data $[28,29]$ and the equation is same as below:

$$
\begin{gathered}
P_{\text {delta }}=\mathrm{GCM}_{P-\text { future,monthly }} \div \mathrm{GCM}_{P-\text { baseline, monthly }} \\
\operatorname{RGCM}_{P-\text { future,daily }}=O B S_{P-\text { baseline,daily }} \times P_{\text {delta }}
\end{gathered}
$$

where, $P_{\text {delta }}$ indicates precipitation biases in GCM data, $\mathrm{GCM}_{\text {future,monthly }}$ and $\mathrm{GCM}_{\text {baseline,monthly }}$ indicate monthly average GCM-driven precipitation for the future (2083-2098) and baseline (1999-2014) periods, respectively, $O B S_{\text {baseline,daily }}$ indicates observed daily precipitation, and $R G C M_{\text {future,daily }}$ indicates bias-corrected future precipitation data. Solar radiation, humidity, and wind speed for the future period were generated using WXGEN with two GCM datasets: (1) original temperature and 
precipitation (referred to as EGCM) and (2) original temperature and modified precipitation using the delta change (referred to as RGCM). Original temperature data were directly used without application of delta change method. In addition, the same $\mathrm{CO}_{2}$ concentration ( $330 \mathrm{ppm}$ ) and agricultural land management were set for the baseline and future simulations to disregard the impacts of different $\mathrm{CO}_{2}$ conditions and input agrochemicals on the fluxes of hydrologic variables, which allowed only consideration of the impacts of wet days. Note that the SWAT default value of $\mathrm{CO}_{2}$ concentration was used in this study. We calculated the ensemble mean of simulated outputs from eight EGCM and RGCM for individual RCPs for comparative analysis.

\subsection{Model Calibration and Validation}

SWAT was calibrated and validated against observed data collected at the TCW outlet. Model simulations were comprised of a two-year warm up (1999-2000), eight-year calibration (2001-2008), and six-year validation (2009-2014) periods. Note that the model was simulated at a daily time step using daily climate data, but the outputs were aggregated at a monthly time step. The parameters used for calibration were selected based on previous literature (Table 3) [22]. The selected parameters were adjusted within allowable ranges until the simulation results met the acceptable statistical performance measures proposed by Moriasi, et al. [30]. Three statistical performance measures used for the calibration and validation are the Nash-Sutcliffe efficiency coefficient (NSE), root-mean-square error (RMSE), standard deviation ratio (RSR), and percent bias (P-bias):

$$
\begin{gathered}
\mathrm{NSE}=1-\left[\frac{\sum_{i=1}^{n}\left(O_{i}-S_{i}\right)^{2}}{\sum_{i=1}^{n}\left(O_{i}-\bar{O}\right)^{2}}\right] \\
\mathrm{RSR}=\frac{\mathrm{RMSE}_{\mathrm{STDEV}} \mathrm{obs}}{\mathrm{ST}^{2}}=\frac{\left[\sqrt{\sum_{i=1}^{n}\left(O_{i}-S_{i}\right)^{2}}\right]}{\left[\sum_{i=1}^{n}\left(O_{i}-\bar{O}\right)^{2}\right]} \\
\mathrm{P}-\text { bias }=\left[\frac{\sum_{i=1}^{n}\left(O_{i}-S_{i}\right) \times 100}{\sum_{i=1}^{n} O_{i}}\right]
\end{gathered}
$$

where, $O_{i}$ are observed and $S_{i}$ are simulated data, $\bar{O}$ are observed mean values, and $n$ equals the number of observations. We also conducted uncertainty analysis using 95 percent prediction uncertainty (PPU). The 95 PPU value was set as followings: all simulations generated during the calibration process were sorted and then the top and bottom $2.5 \%$ of simulations were used to represent the uncertainty range [31]. We also calculated P-factor to quantify the proportion of observed data within 95 PPU [31]. To calibrate crop biomass parameters, simulated crop yields were compared with observed ones, and

\begin{tabular}{|c|c|c|c|c|}
\hline Parameter & Variable & Description (Unit) & Range & Value \\
\hline $\mathrm{CN} 2{ }^{\#}$ & & Curve number & $-50-50 \%$ & $-30 \%$ \\
\hline ESCO \# & & Soil evaporation compensation factor & $0-1$ & 1 \\
\hline SURLAG $\#$ & & Surface runoff lag coefficient & $0.5-24$ & 0.5 \\
\hline SOL_AWC $\#$ & & Available water capacity of the soil layer $\left(\mathrm{mm} \mathrm{H}_{2} \mathrm{O} \cdot \mathrm{mm} \mathrm{soil}^{-1}\right)$ & $-50-50 \%$ & $-10 \%$ \\
\hline SOL_K $\#$ & & Saturated hydraulic conductivity $\left(\mathrm{mm} \cdot \mathrm{h}^{-1}\right)$ & $-50-50 \%$ & $50 \%$ \\
\hline SOL_Z \# & & Depth from soil surface to bottom of layer (mm) & $-50-50 \%$ & $-20 \%$ \\
\hline ALPHĀ_BF \# & Streamflow & Base flow recession constant $\left(1 \cdot\right.$ days $\left.^{-1}\right)$ & $0-1$ & 0.07 \\
\hline GW_DELAY\# & & Groundwater delay time (days) & $0-500$ & 130 \\
\hline GW_REVAP \# & & Groundwater "revap" coefficient & $0.02-0.2$ & 0.10 \\
\hline RCHRG_DP \# & & Deep aquifer percolation fraction & $0-1$ & 0.01 \\
\hline GWQMN \# & & $\begin{array}{l}\text { Threshold depth of water in the shallow aquifer required for return } \\
\text { flow to occur (mm) }\end{array}$ & $0-5000$ & 1.9 \\
\hline $\mathrm{CH} \_\mathrm{K} 2 \#$ & & Effective hydraulic conductivity $\left(\mathrm{mm} \cdot \mathrm{h}^{-1}\right)$ & $0-150$ & 0 \\
\hline $\mathrm{CH} \_\mathrm{N} 2{ }^{\#}$ & & Manning coefficient & $0.01-0.3$ & 0.29 \\
\hline
\end{tabular}
P-bias was chosen as a performance measure as it was widely employed in the previous studies [32,33].

Table 3. List of calibrated parameters. 
Table 3. Cont.

\begin{tabular}{|c|c|c|c|c|}
\hline Parameter & Variable & Description (Unit) & Range & Value \\
\hline $\mathrm{NPERCO}^{+}$ & & Nitrogen percolation coefficient & $0.01-1$ & 0.5 \\
\hline N_UPDIS ${ }^{+}$ & & Nitrogen uptake distribution parameter & $5-50$ & 50 \\
\hline ANION_EXCL ${ }^{+}$ & & Fraction of porosity from which anions are excluded & $0.1-0.7$ & 0.59 \\
\hline $\mathrm{ERORGN}^{+}$ & Nitrate & Organic $\mathrm{N}$ enrichment ratio for loading with sediment & $0-5$ & 4.92 \\
\hline BIOMIX ${ }^{+}$ & Nitrate & Biological mixing efficiency & $0.01-1$ & 0.01 \\
\hline SOL_NO3 $\S$ & & Initial NO3 concentration in soil layer $\left(\mathrm{mg} \mathrm{N} \cdot \mathrm{kg}^{-1}\right)$ & $0-100$ & 11.23 \\
\hline $\mathrm{CDN}^{\$}$ & & Denitrification exponential rate coefficient & $0-3.0$ & 0.7 \\
\hline $\mathrm{SDNCO}^{\$}$ & & Denitrification threshold water content & $0.1-1.1$ & 1.0 \\
\hline HVSTI \& & \multirow{6}{*}{ Yield } & Harvest index for optimal growing conditions & $0.5-0.7$ & $\begin{array}{l}\text { Corn } 0.64 \\
\text { Soyb } 0.39\end{array}$ \\
\hline BLAI \& & & Maximum potential leaf area index & $5-8$ & $\begin{array}{l}\text { Corn } 7.3 \\
\text { Soyb } 4.4\end{array}$ \\
\hline FRGRW1 ${ }^{\dagger}$ & & $\begin{array}{l}\text { Fraction of the plant growing season of total potential heat units } \\
\text { corresponding to the first point on the leaf area development curve }\end{array}$ & - & $\begin{array}{l}\text { Corn } 0.05 \\
\text { Soyb } 0.03\end{array}$ \\
\hline FRGRW2 ${ }^{+}$ & & $\begin{array}{l}\text { Fraction of the plant growing season of total potential heat units } \\
\text { corresponding to the second point on the leaf area development curve }\end{array}$ & - & $\begin{array}{l}\text { Corn } 0.39 \\
\text { Soyb } 0.39\end{array}$ \\
\hline $\operatorname{LAIMX}^{+}$ & & $\begin{array}{l}\text { Fraction of the maximum leaf area index corresponding to the first } \\
\text { point on the leaf area development curve }\end{array}$ & - & $\begin{array}{l}\text { Corn } 0.80 \\
\text { Soyb } 0.56\end{array}$ \\
\hline $\operatorname{LAIMX} 2^{+}$ & & $\begin{array}{c}\text { Fraction of the maximum leaf area index corresponding to the second } \\
\text { point }\end{array}$ & - & $\begin{array}{l}\text { Corn } 0.98 \\
\text { Soyb } 0.99\end{array}$ \\
\hline
\end{tabular}

Note: Soyb stands for "soybean". The ranges of parameters with superscripts $\left({ }^{\dagger}, \$, \#, \S\right.$ and $\left.{ }^{\&}\right)$ were adapted from Yeo, et al. [13], Neitsch, et al. [18], Gitau and Chaubey, [34], Seo, et al. [35], and Parajuli, et al. [36], respectively.

\subsection{Comparison Approach}

We first compared the monthly average precipitation and wet days between EGCM and RGCM, and then solar radiation was analyzed because solar radiation generated from a weather generator is highly sensitive to the number of wet days [18]. Relative humidity and wind speed from a weather generator were not considered since SWAT only provides daily solar radiation from a weather generator. PET was compared as its calculation is affected by solar radiation. After analyzing precipitation and PET, hydrologic variables simulated by SWAT using the two climate datasets (EGCM and RGCM) were compared and considered hydrologic variables were: ET, streamflow, and nitrate loads. Lastly, predicted crop biomass using EGCM and RGCM was compared to demonstrate importance of climate on simulating crop growth. Even though crop yield was calibrated against observations, we analyzed crop biomass because climatic variability has impacts on the total biomass growth including above and belowground portions in SWAT [18], and therefore the total biomass better represents how crop growth responds to climatic conditions compared to simulated crop yield accounting for the portion of aboveground biomass in SWAT [18]. Climate data and predicted SWAT outputs for the baseline period were simultaneously examined with those from EGCM and RGCM.

\section{Results and Discussions}

\subsection{Model Calibration and Validation}

Monthly simulations of streamflow and nitrate loads were compared with corresponding observations (Figure 2). Comparison results showed that a calibrated model well replicated seasonal and annual variations of observed streamflow. Simulated nitrate loads were also consistent with observations. In addition, most observations were shown to be within the uncertainty band (shown as green in Figure 2). In compliance with graphical comparisons, model performance measures indicated "good" or "very good" for streamflow and more than "satisfactory" for nitrate loads (Table 4). The P-bias was $-4.9 \%$ and $2.6 \%$ for corn and soybean, respectively (Figure 3), which indicates SWAT slightly over- and under-estimated corn and soybean, respectively, compared to observations. Our crop calibration results, however, indicated a fairly good consistency between observations and simulations when compared to the previous studies by Srinivasan, et al. [32] with P-bias of $-1-28 \%$ and Woznicki, et al. [33] with P-bias of 1.9-9.4\%. 


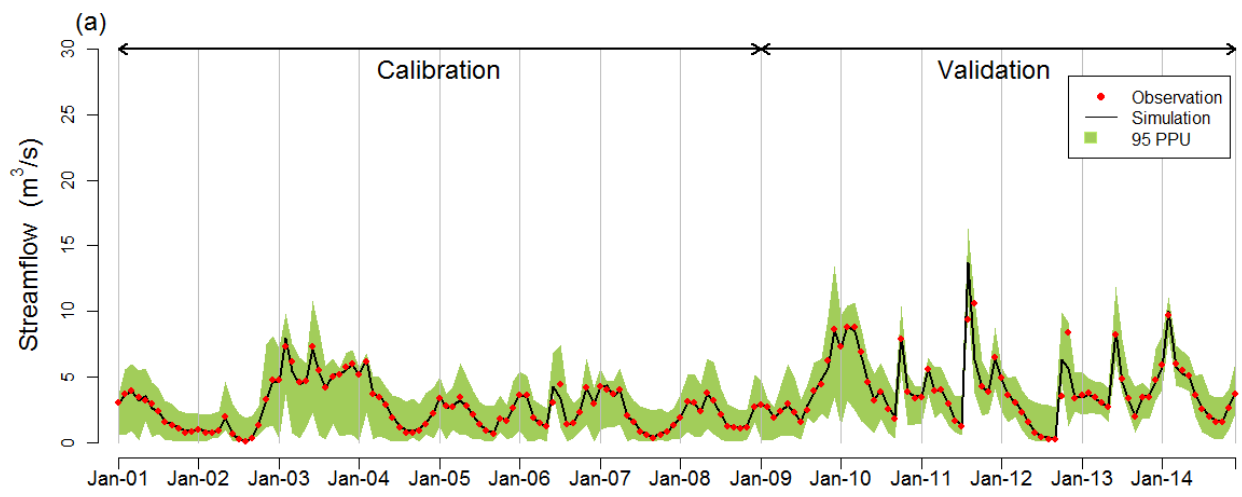

(b)

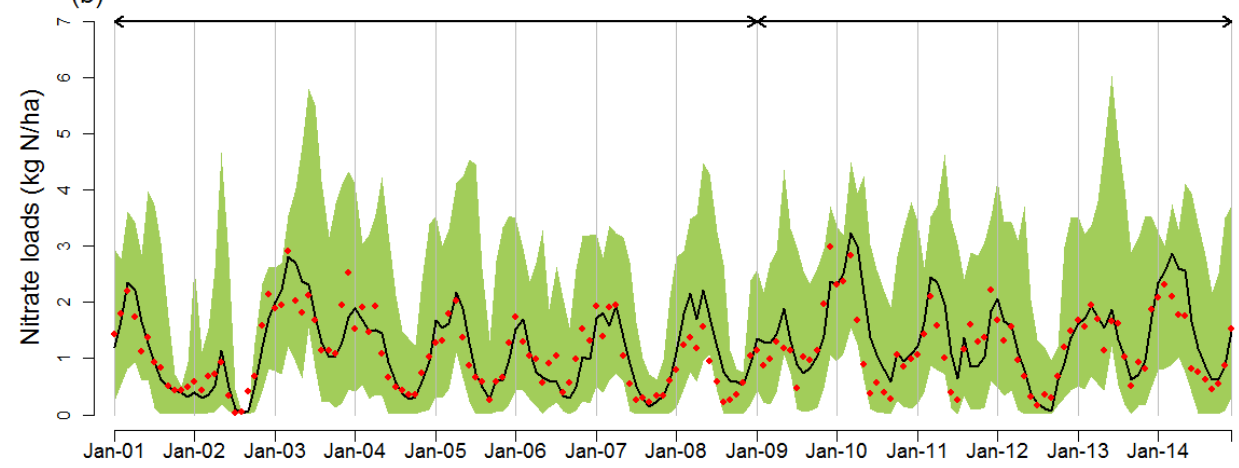

Figure 2. Comparison of observed and simulated monthly (a) streamflow and (b) nitrate loads under the baseline period.
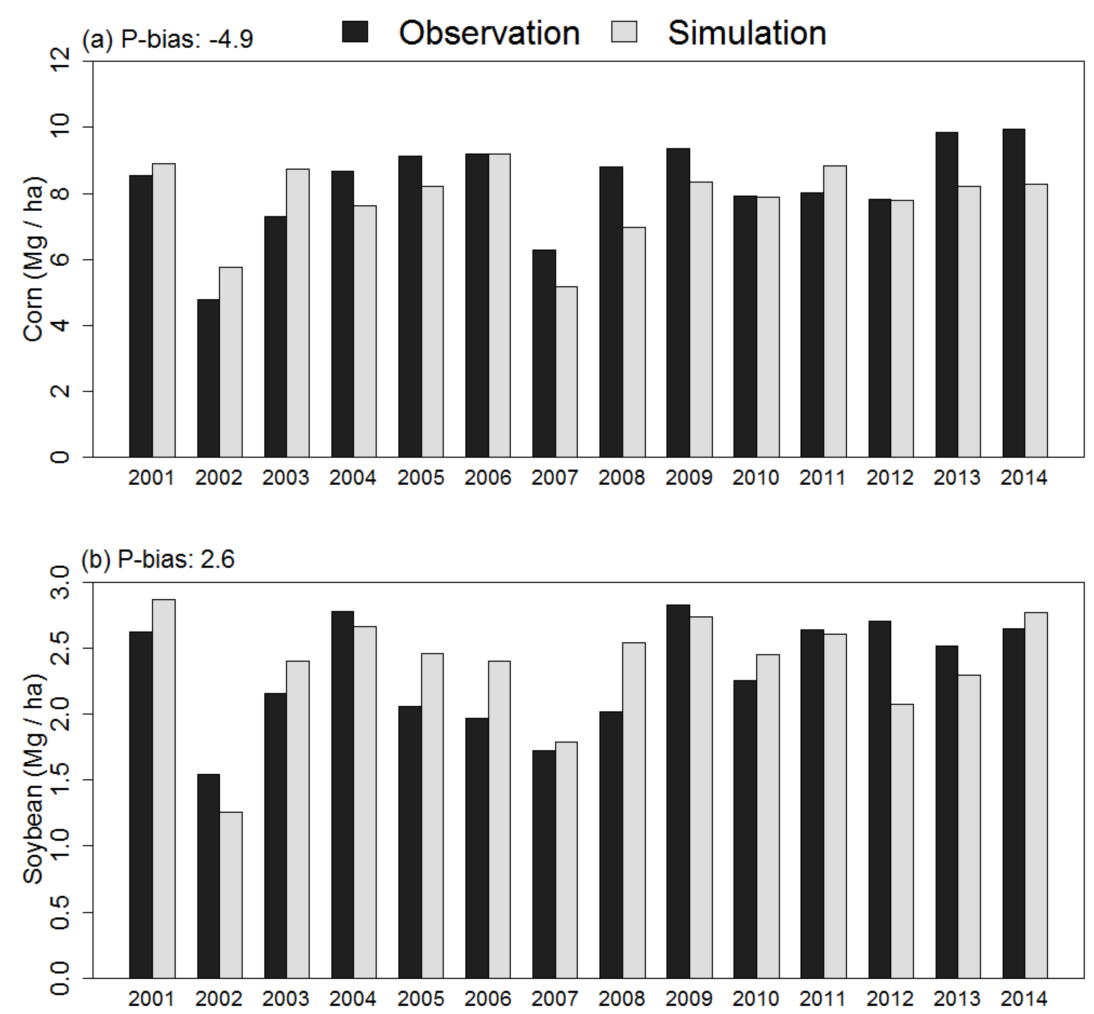

Figure 3. Comparison of observed and simulated (a) corn and (b) soybean yields under the baseline period. 
Table 4. Model performance measures for monthly streamflow and nitrate loads.

\begin{tabular}{llcccc}
\hline & Period & NSE & RSR & P-bias & $p$-Value \\
\hline \multirow{2}{*}{ Streamflow } & Calibration & $0.705^{* *}$ & $0.542^{* *}$ & $10.5^{* *}$ & 0.99 \\
& Validation & $0.703^{* *}$ & $0.544^{* *}$ & $-12.6^{* *}$ & 0.97 \\
\hline \multirow{2}{*}{ Nitrate loads } & Calibration & $0.738^{* *}$ & $0.511^{* *}$ & $-3.5^{* * *}$ & 0.99 \\
& Validation & $0.515^{*}$ & $0.696^{*}$ & $-14.9^{* *}$ & 1 \\
\hline
\end{tabular}

Model performances were rated based on the criteria of Moriasi, et al. [30]; ${ }^{*}$ Satisfactory; ** Good; and * Satisfactory $(0.5<\mathrm{NSE} \leq 0.65,0.6<\mathrm{RSR} \leq 0.7$, and $\pm 15 \leq \mathrm{P}$-bias $< \pm 25),{ }^{* *}$ Good $(0.65<\mathrm{NSE} \leq 0.75,0.5<\mathrm{RSR} \leq 0.6$, and \pm $10 \leq$ P-bias $< \pm 15)$, and *** Very Good $(0.75<\mathrm{NSE} \leq 1.0,0.0<\mathrm{RSR} \leq 0.5$, P-bias $< \pm 10)$.

\subsection{Climate Variables}

The monthly average precipitation and wet days of EGCM and RGCM are presented in Figure 4. Overall, the monthly average precipitation of RGCM was greater than EGCM (Figure 4a,b). EGCM was slightly greater than or similar to RGCM from January to March For the rest of months, RGCM was greater than EGCM by up to $38 \mathrm{~mm}$. Note that the annual average precipitation of RGCM was 100-107 mm greater than EGCM. The annual average precipitation of EGCM was similar to or slightly greater than the baseline while RGCM was 50-128 mm greater than the baseline. The monthly average precipitation differed between EGCM and RGCM, but the variation range of monthly precipitation of the two datasets was not abnormal and comparable each other. However, the monthly average wet days of EGCM were abnormally greater than RGCM (Figure 4c,d). The monthly average wet days of EGCM ranged from 22 to 29 days while those of RGCM were from 8 to 11 days. The monthly average wet days were identical for the baseline and RGCM due to the delta change method (Figure 4d). As pointed out the previous studies [16,17], EGCM indicated excessive wet days and most of wet days are light rain with $<10 \mathrm{~mm}$ (Figure S3).
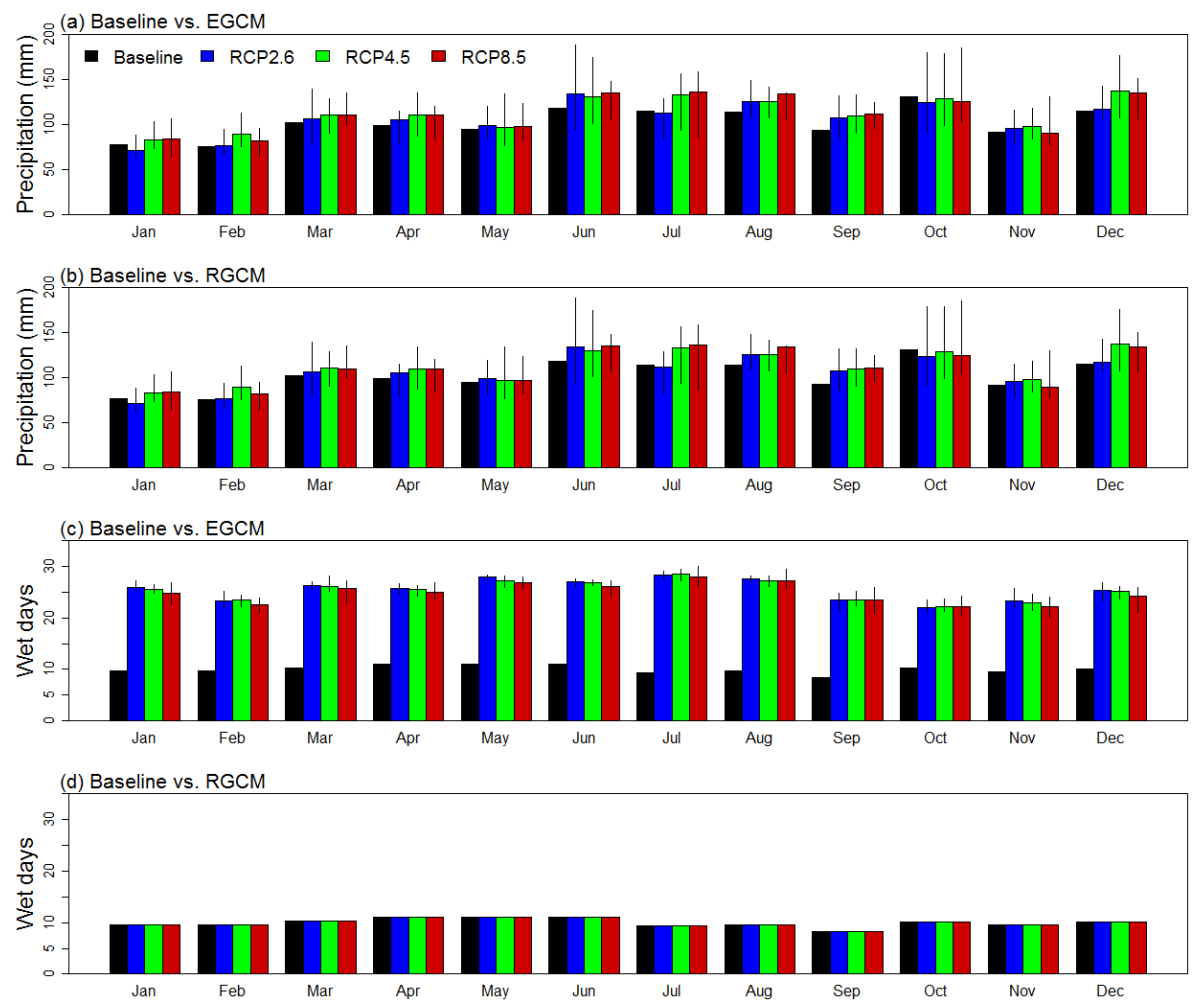

Figure 4. Comparison of the monthly average $(\mathbf{a}, \mathbf{b})$ precipitation and $(\mathbf{c}, \mathbf{d})$ wet days of EGCM (GCM with the excessive number of wet days) and RGCM(GCM with the reasonable number of wet days). 
The estimated values of solar radiation from $\operatorname{EGCM~}\left(4-15 \mathrm{MJ} / \mathrm{m}^{2}\right)$ were underestimated compared to those from RGCM $\left(6-21 \mathrm{MJ} / \mathrm{m}^{2}\right.$, Figure $\left.5 \mathrm{a}, \mathrm{b}\right)$. WXGEN adjusts solar radiation for wet or dry conditions based on the number of dry or wet days in the month [18]. Hence, the excessive number of wet days of EGCM likely resulted in underestimation of solar radiation. The monthly average PET estimated from EGCM (19-113 mm) was substantially lower compared to RGCM (35-196 mm, Figure $5 c, d$ ), because of underestimated solar radiation. The annual average PET from EGCM was 515-546 mm lower than RGCM. Note that the monthly average temperature for the future period was $1-2{ }^{\circ} \mathrm{C}(\mathrm{RCP} 2.6), 2-3{ }^{\circ} \mathrm{C}(\mathrm{RCP} 4.5)$, and $4-6{ }^{\circ} \mathrm{C}$ (RCP8.5) warmer than the baseline value (Figure 5e).

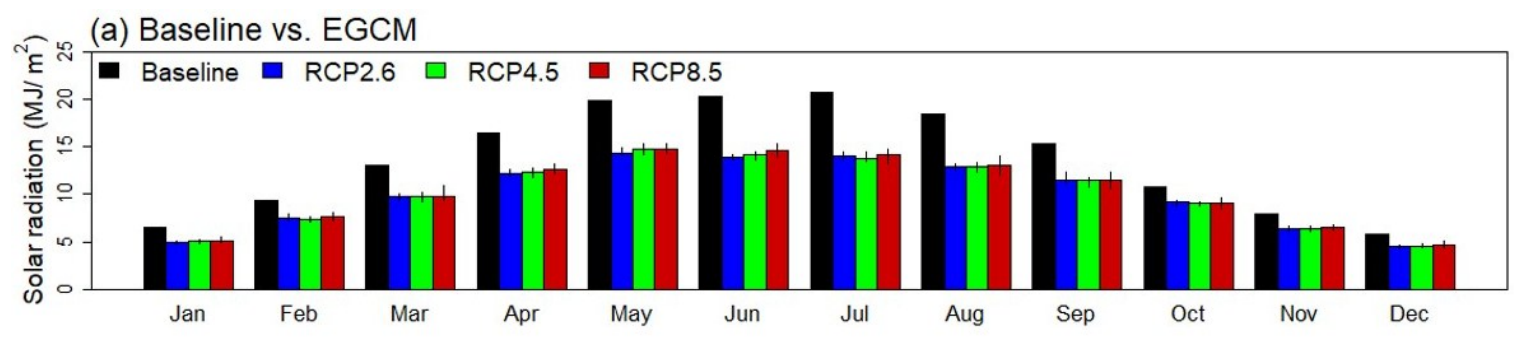

(b) Baseline vs. RGCM

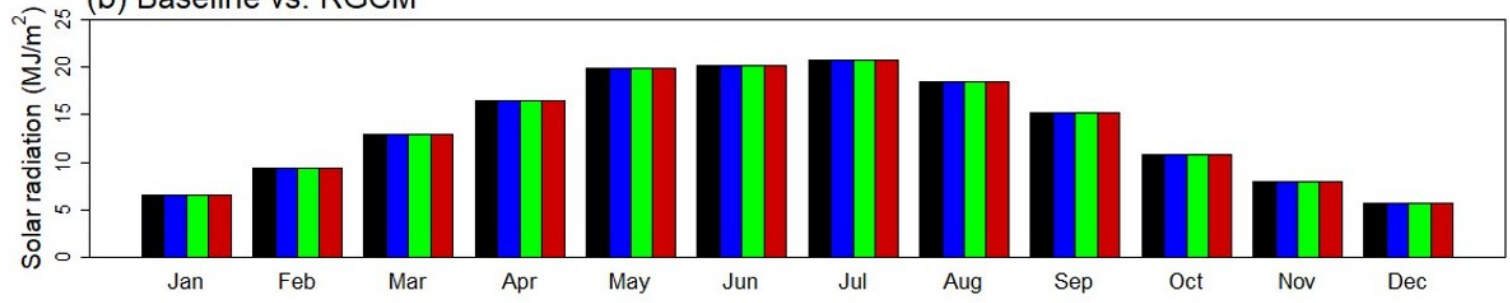

(c) Baseline vs. EGCM

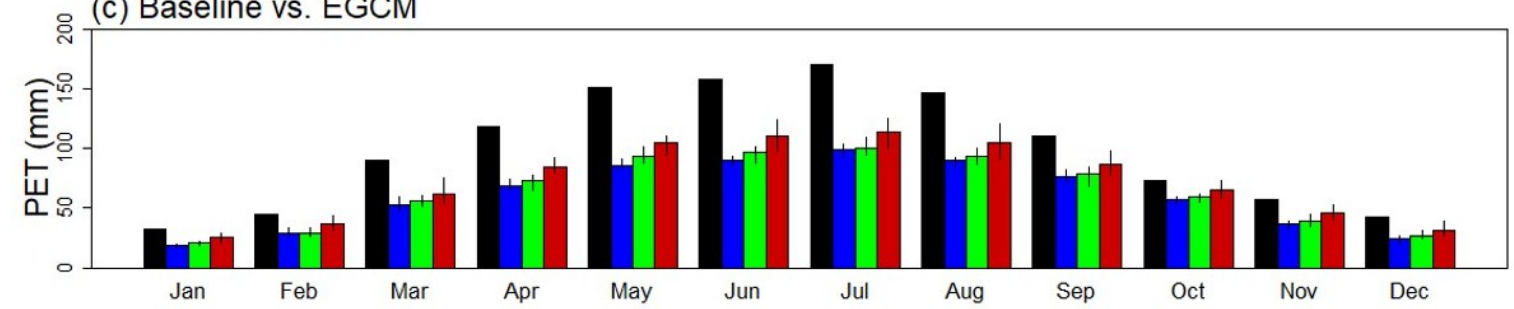

(d) Baseline vs. RGCM

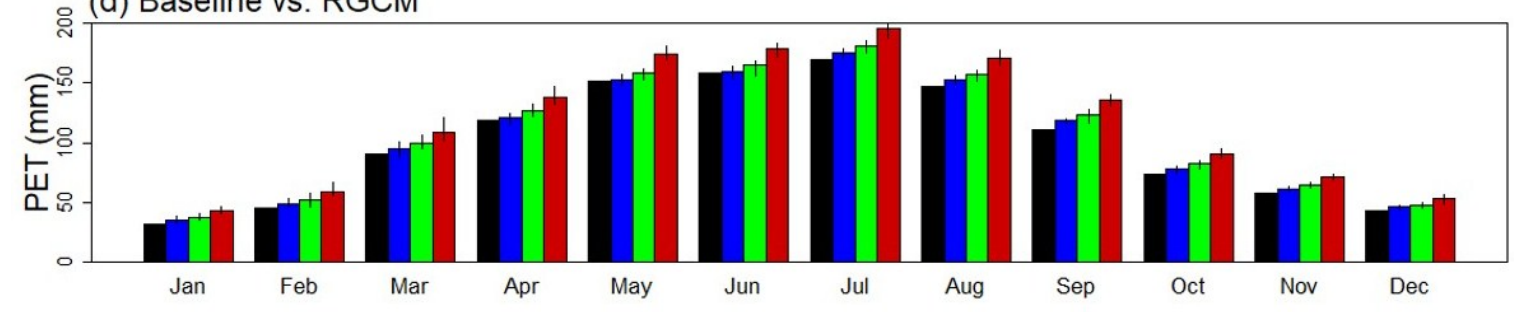

(e) Baseline vs. EGCM and RGCM

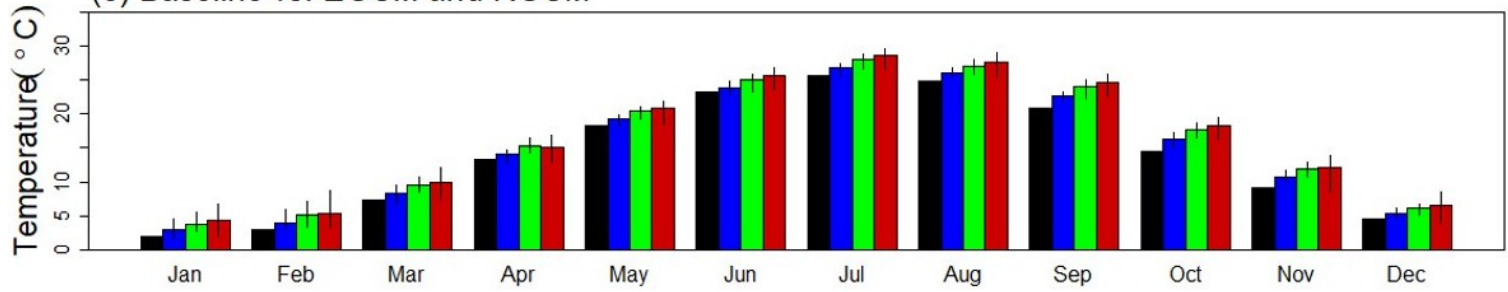

Figure 5. Comparison of the monthly average $(\mathbf{a}, \mathbf{b})$ solar radiation; $(\mathbf{c}, \mathbf{d})$ PET; and (e) temperature estimated using EGCM and RGCM. 


\subsection{Hydrologic Variables}

The hydrologic variables simulated from EGCM and RGCM are shown in Figure 6. The annual average ET from EGCM (490-537 mm) was $143 \mathrm{~mm}$ lower than RGCM (639-673 mm), due to lower PET (Figure 6a). Compared to the baseline value $(632 \mathrm{~mm})$, ET from EGCM decreased by $95-141 \mathrm{~mm}$ while ET from RGCM increased by 7-41 $\mathrm{mm}$. Streamflow from EGCM was $1.0-1.3 \mathrm{~m}^{3} / \mathrm{s}$ greater than the baseline and $0.6-0.8 \mathrm{~m}^{3} / \mathrm{s}$ greater than RGCM (Figure $6 \mathrm{~b}$ ), due to less water loss by ET. However, the EGCM simulation results were in opposition to previous findings $[10,37,38]$. For example, warmer temperatures tended to increase ET, subsequently reducing the water budget $[10,37,38]$. In our study, ET from EGCM appeared to be lower than the baseline value (Figure 6) despite $1-6{ }^{\circ} \mathrm{C}$ warmer temperatures (Figure 5e) and similar annual precipitation. In addition, annual precipitation of EGCM was approximately $100 \mathrm{~mm}$ lower than RGCM (Figure 4), but streamflow from EGCM was greater than RGCM. These findings also contradicted previous studies reporting greater streamflow with increased precipitation $[10,37,38]$. On the contrary, simulations from RGCM were consistent with climate conditions. For example, ET from RGCM was $22 \mathrm{~mm}$ greater than the baseline due to warmer temperature and therefore streamflow from RGCM was also $0.4 \mathrm{~m}^{3} / \mathrm{s}$ greater than the baseline due to substantially increased precipitation.
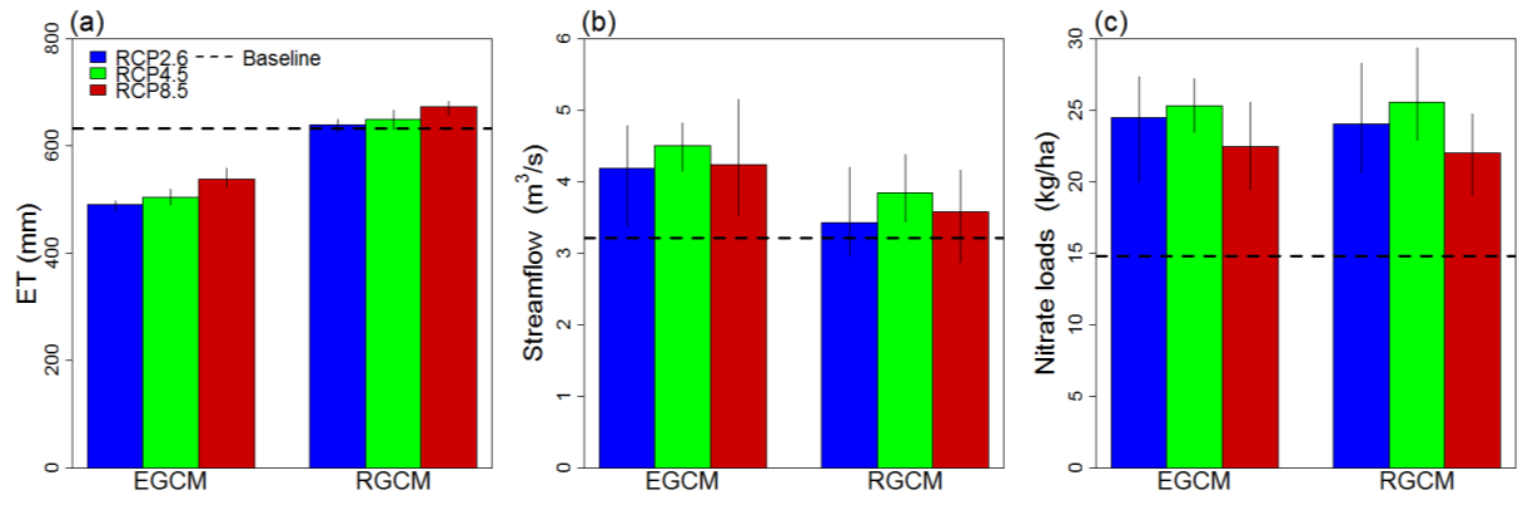

Figure 6. The annual average hydrologic variables predicted using EGCM and RGCM: (a) ET; (b) streamflow; and (c) nitrate loads.

Predicted nitrate loads from EGCM might be also overestimated as nitrate transport is highly dependent on the water cycle $[39,40]$. Interestingly, nitrate loads from RGCM were shown to be almost equal to EGCM even though streamflow was lower (Figure $6 b, c)$. This was likely because increased precipitation of RGCM on April, when $72 \%$ of fertilizers were applied, led to substantial export of fertilizer-driven nitrate, resulting in a similar amount of nitrate loads with EGCM (Figure 4). Lee, et al. [41] also found that an increase in nitrate export by precipitation increase was substantial for the months with fertilizer applications. Overall, the water budget predicted from EGCM was not reasonable when compared with climate conditions while the one from RGCM was consistent with climate condition. This was likely attributed to the poorly predicted PET resulting from excessive wet days of EGCM.

\subsection{Crop Biomass}

Predicted crop biomass values using EGCM and RGCM are provided on Figure 7. Corn and soybean biomass from RGCM were 0.3 and $2 \mathrm{Mg}$ /ha greater than those from EGCM, respectively, due to underestimated solar radiation of EGCM. As shown in Figure 7c,d, solar radiation of EGCM was underestimated due to the excessive wet days, which likely resulted in lowering crop biomass because solar radiation is a key component affecting crop biomass growth [18]. A cumulative daily solar radiation of RGCM for the corn and soybean growth periods was $266-367 \mathrm{MJ} / \mathrm{m}^{2}$ and $235-323 \mathrm{MJ} / \mathrm{m}^{2}$ greater than EGCM, respectively (Figure 7c,d). Under EGCM, RCP8.5 indicated greater solar radiation 
than RCP2.6 and 4.5 as its monthly wet days are less than the two RCPs (Figure 4c). All RCPs under RGCM have the same solar radiation as the baseline due to the same number of wet days per a month. Relative to soybean, the difference in corn biomass between EGCM and RGCM was smaller because greater precipitation of RGCM incurred an increased export of nitrogen from fertilizer applications and subsequently greater nutrient stress, prohibiting crop biomass growth (Figure 7a,b) [41,42]. As a result, corn biomass under EGCM and RGCM was similar in spite of greater solar radiation in RGCM compared to EGCM. In contrast, soybean growth was not restricted by nitrogen loss resulting from precipitation increase as it can provide required nutrients through biological fixation. Therefore, soybean biomass under RGCM was noticeably greater than EGCM.

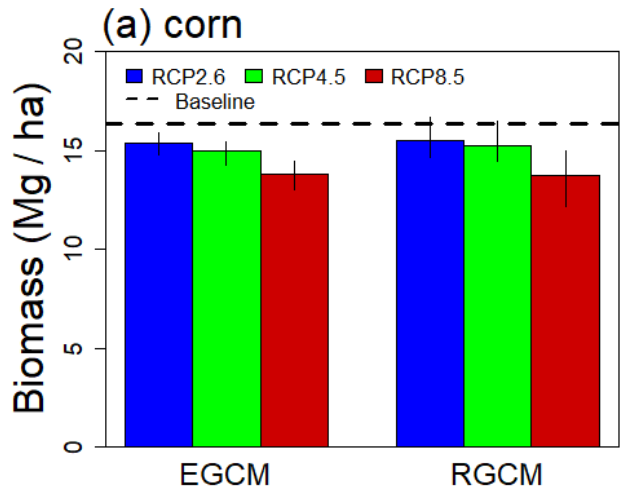

(c) corn

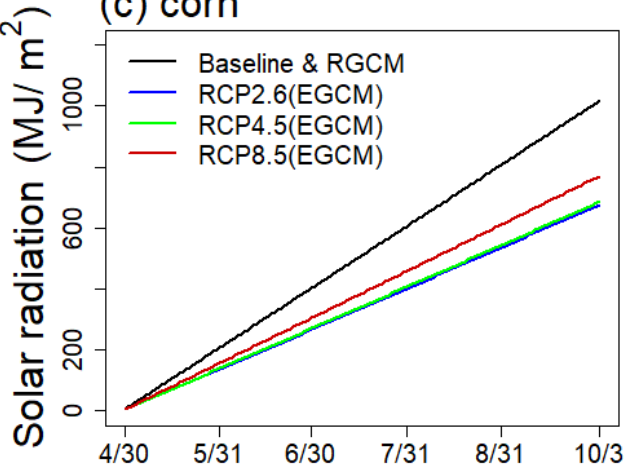

(b) soybean

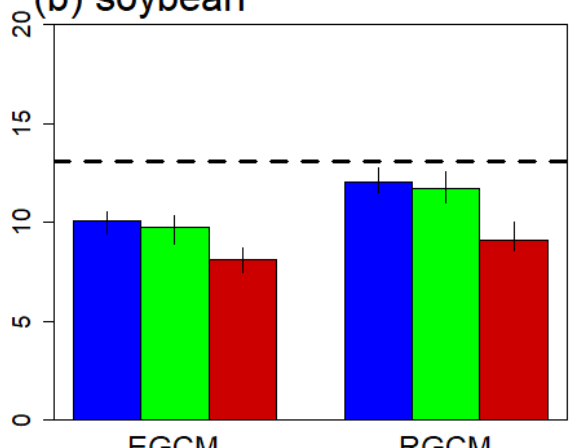

(d) soybean

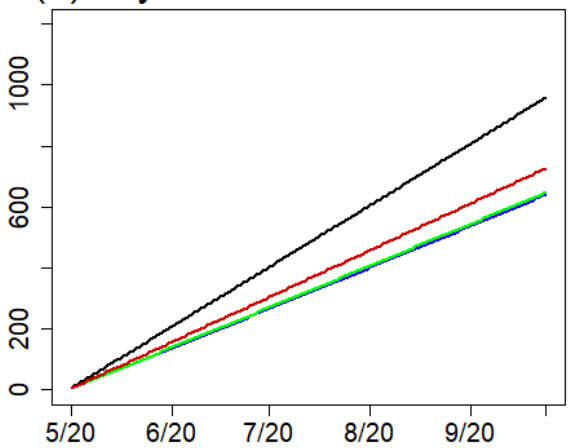

Figure 7. The annual average crop biomass $(\mathbf{a}, \mathbf{b})$ and daily average of cumulative solar radiation $(\mathbf{c}, \mathbf{d})$.

Poor prediction of PET likely led to unreasonable crop water stress in response to EGCM (Figure 8). Crop water stress under EGCM was significantly lower than RGCM (Figure 8), because underestimated ET by EGCM increased water availability for crop growth. However, this simulation result was not reasonable considering that crop water stress and relevant agricultural practices (i.e., irrigation) are highly dependent on precipitation and temperature pattern [43]. Under the homogeneous temperature conditions, crops should have less water stress under RGCM with $56 \mathrm{~mm}$ greater precipitation during summer growing seasons (from April to September) compared to EGCM [43]. However, the simulations from EGCM were in disagreement with the climate conditions. 
(a) corn - EGCM

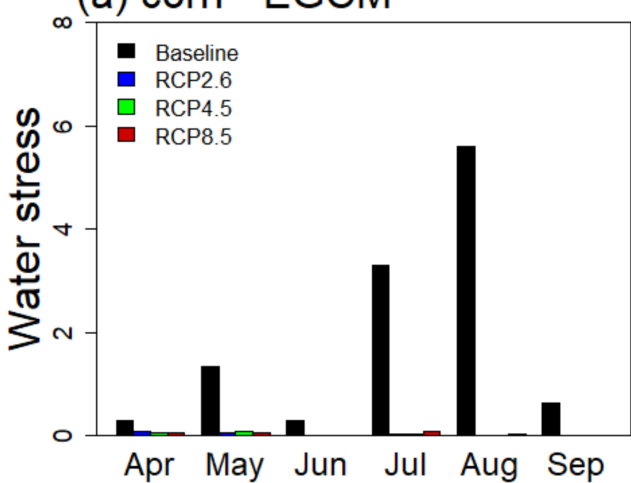

(c) corn - RGCM

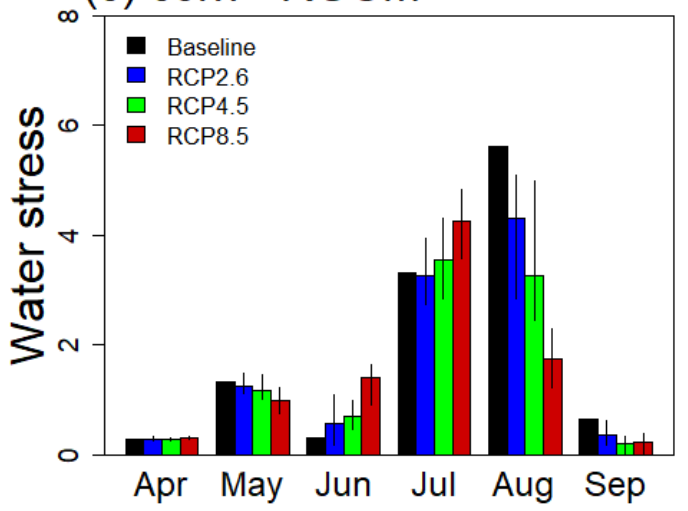

(b) soybean - EGCM

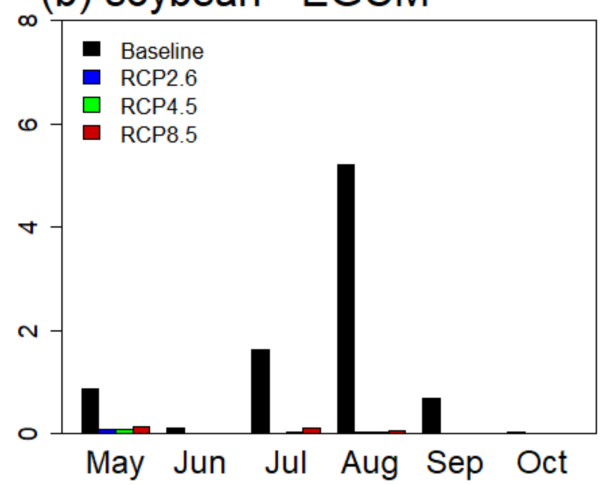

(d) soybean - RGCM

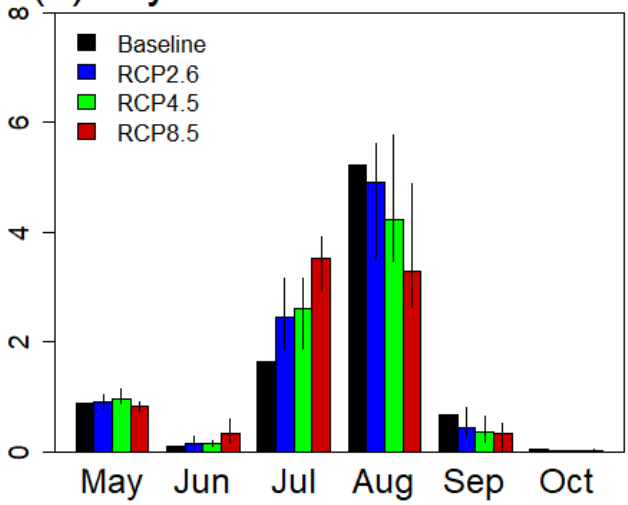

Figure 8. Daily average of cumulative solar radiation and monthly average water stress for corn and soybean.

\section{Limitations and Implications}

Due to the unavailability of detailed relative humidity and wind from WXGEN, this study was limited to representing inaccuracy of relative humidity and wind from WXGEN using EGCM. In conjunction with inaccurate solar radiation, inaccurate relative humidity and wind also contributed to poor predictions of PET by SWAT. Although solar radiation, relative humidity, and wind can be generated from WXGEN using bias-corrected temperature and precipitation, three climate data generated may not fully represent future climate conditions. Instead of generating those climate data, use of GCM-driven data may better represent future conditions, although the data source of solar radiation, relative humidity, and wind can be different from precipitation and temperature regarding limited availability of those GCM-driven data. Thus, comparing simulations from WXGEN- and GCM-driven three climate data would be helpful to guide preparing future climate data.

This study only applied one traditional delta change method to prepare RGCM. Multiple delta change methods exist [44] and those methods potentially lead to GCM with varying degree of reasonable wet days. Thus, climate variables from WXGEN may differ by delta change methods, resulting in different simulated outputs. Consequently, comparing simulation results from multiple delta change methods could show a more reliable method for correcting GCM bias. In the future, investigating the impacts of delta change methods on WXGEN and SWAT would provide important implications on selecting a suitable delta change method.

\section{Summary and Conclusions}

Limitations in GCM data for projecting future conditions using SWAT require that some climate data are prepared by WXGEN weather generator using input of available GCM data. Proper processing of GCM has been highlighted to remove biases and produce reliable climate data applicable to 
local-level studies, but the impact of GCM bias on climate variables from WXGEN and its consequence effects on SWAT simulations have been rarely examined. One of the critical bias is the excessive number of wet days in the original GCM data, which lead to lower solar radiation by WXGEN thus reduce the accuracy of SWAT simulations. This study specifically examined how the excessive wet days in GCM affect simulated hydrologic variables and crop growth using climate variables generated by WXGEN. We compared simulations from WXGEN and SWAT using GCM data with excessive (EGCM) and reasonable (RGCM) number of wet days to demonstrate importance of input data preparation for WXGEN. Our simulation results showed that model predictions from EGCM were inconsistent with climate conditions while those from RGCM were consistent with climate conditions, mainly due to poorly simulated climate variables from WXGEN. Excessive wet days in EGCM led to underestimation of solar radiation from WXGEN, subsequently resulting in lower PET. These underestimations decreased the accuracy of SWAT simulations from EGCM. For example, streamflow from EGCM was $0.6-0.8 \mathrm{~m}^{3} / \mathrm{s}$ greater than those from RGCM in spite of $100 \mathrm{~mm}$ lower EGCM precipitation relative to RGCM. In addition, crop water stress from EGCM was considerably lower than those under RGCM even though EGCM precipitation during crop growing seasons was $56 \mathrm{~mm}$ lower than RGCM. Our findings demonstrate that GCM bias (excessive wet days) causes WXGEN to generate inaccurate climate variables and therefore leads to unreasonable SWAT simulations. Regarding increased availability of GCM data, more caution should be placed on processing of GCM data to use them for a weather generator.

Supplementary Materials: The following are available online at http:/ /www.mdpi.com/2073-4441/10/6/764/s1, Figure S1: The number of rain days of EGCM and RGCM at individual bins for the entire period, Table S1: Description of eight general circulation models (GCMs) used for this study, Equation (S1): Penman-Monteith method.

Author Contributions: S.L. developed methodology and performed most analysis and writing; C.W.W. performed analysis and helped with writing; A.M.S. and G.W.M. lead the data collection and supervised the project; H.Z. and I.-Y.Y. were instrumental in writing and data analysis.

Funding: This research was funded by the US Department of Agriculture (USDA) Natural Resources Conservation Service (NRCS) Conservation Effects Assessment Project (CEAP) grant number (67-3A75-17-473).

Acknowledgments: We sincerely appreciate the reviewers for their valuable time and effort that resulted in significant improvement to this publication. We also appreciate Journal Editor Board for their help and patience throughout the review process.

Conflicts of Interest: The authors declare no conflict of interest. The funding sponsors had no role in the design of the study, in the collection, analyses, or interpretation of data, in the writing of the manuscript, and in the decision to publish the results.

\section{References}

1. Mearns, L.O.; Hulme, M.; Carter, T.R.; Leemans, R.; Lal, M.; Whetton, P. Climate scenario development. In Climate Change 2007: The Physical Science Basis. Contribution of Working Group I to the Fourth Assessment Report of the Intergovernmental Panel on Climate Change; Solomon, S., Qin, D., Manning, M., Chen, Z., Marquis, M., Averyt, K.B., Tignor, M., Miller, H.L., Eds.; Cambridge University Press: Cambridge, UK; New York, NY, USA, 2007.

2. Chen, J.; Brissette, F.P.; Poulin, A.; Leconte, R. Overall uncertainty study of the hydrological impacts of climate change for a Canadian watershed. Water Resour. Res. 2011, 47. [CrossRef]

3. Teutschbein, C.; Seibert, J. Bias correction of regional climate model simulations for hydrological climate-change impact studies: Review and evaluation of different methods. J. Hydrol. 2012, 456, 12-29. [CrossRef]

4. Goddard, L.; Mason, S.J.; Zebiak, S.E.; Ropelewski, C.F.; Basher, R.; Cane, M.A. Current approaches to seasonal to interannual climate predictions. Int. J. Climatol. 2001, 21, 1111-1152. [CrossRef]

5. Nyunt, C.T.; Koike, T.; Yamamoto, A. Statistical bias correction for climate change impact on the basin scale precipitation in Sri Lanka, Philippines, Japan and Tunisia. Hydrol. Earth Syst. Sci. 2016. [CrossRef]

6. Wood, A.W.; Leung, L.R.; Sridhar, V.; Lettenmaier, D.P. Hydrologic implications of dynamical and statistical approaches to downscaling climate model outputs. Clim. Chang. 2004, 62, 189-216. [CrossRef] 
7. Ines, A.V.; Hansen, J.W.; Robertson, A.W. Enhancing the utility of daily GCM rainfall for crop yield prediction. Int. J. Climatol. 2011, 31, 2168-2182. [CrossRef]

8. Gassman, P.W.; Sadeghi, A.M.; Srinivasan, R. Applications of the SWAT model special section: Overview and insights. J. Environ. Qual. 2014, 43, 1-8. [CrossRef] [PubMed]

9. Alighalehbabakhani, F.; Miller, C.J.; Selegean, J.P.; Barkach, J.; Abkenar, S.M.S.; Dahl, T.; Baskaran, M. Estimates of sediment trapping rates for two reservoirs in the Lake Erie watershed: Past and present scenarios. J. Hydrol. 2017, 544, 47-155. [CrossRef]

10. Ficklin, D.L.; Luo, Y.; Luedeling, E.; Zhang, M. Climate change sensitivity assessment of a highly agricultural watershed using SWAT. J. Hydrol. 2009, 374, 16-29. [CrossRef]

11. Wallace, C.W.; Flanagan, D.C.; Engel, B.A. Quantifying the Effects of Future Climate Conditions on Runoff, Sediment, and Chemical Losses at Different Watershed Sizes. Trans. ASABE 2017, 60, 915-929. [CrossRef]

12. Wang, R.; Kalin, L.; Kuang, W.; Tian, H. Individual and combined effects of land use/cover and climate change on Wolf Bay watershed streamflow in southern Alabama. Hydrol. Process. 2014, 28, 5530-5546. [CrossRef]

13. Yeo, I.Y.; Lee, S.; Sadeghi, A.M.; Beeson, P.C.; Hively, W.D.; McCarty, G.W.; Lang, M.W. Assessing winter cover crop nutrient uptake efficiency using a water quality simulation model. Hydrol. Earth Syst. Sci. 2014, 18, 5239-5253. [CrossRef]

14. Rodríguez-Blanco, M.L.; Arias, R.; Taboada-Castro, M.M.; Nunes, J.P.; Keizer, J.J.; Taboada-Castro, M.T. Potential Impact of Climate Change on Suspended Sediment Yield in NW Spain: A Case Study on the Corbeira Catchment. Water 2016, 8, 444. [CrossRef]

15. Sharpley, A.N.; Williams, J.R.; United States Agricultural Research Service. Erosion/Productivity Impact Calculator, 1. Model Documentation; U.S. Department of Agriculture, Agricultural Research Service: Washington, DC, USA, 1990.

16. Chen, H.; Sun, J. Projected change in East Asian summer monsoon precipitation under RCP scenario. Meteorol. Atmos. Phys. 2013, 121, 55-77. [CrossRef]

17. Chen, H.; Sun, J.; Chen, X. Projection and uncertainty analysis of global precipitation-related extremes using CMIP5 models. Int. J. Climatol. 2014, 34, 2730-2748. [CrossRef]

18. Neitsch, S.L.; Arnold, J.G.; Kiniry, J.R.; Williams, J.R. Soil and Water Assessment Tool Theoretical Documentation Version 2009; Texas Water Resources Institute Technical Report; Texas A\&M University System: College Station, TX, USA, 2011.

19. Brekke, L.; Thrasher, B.L.; Maurer, E.P.; Pruitt, T. Downscaled Cmip3 and Cmip5 Climate Projections: Release of Downscaled Cmip5 Climate Projections, Comparison with Preceding Information, and Summary of User Needs; US Department of the Interior, Bureau of Reclamation, Technical Service Center: Denver, CO, USA, 2013.

20. McCarty, G.W.; McConnell, L.L.; Hapeman, C.J.; Sadeghi, A.; Graff, C.; Hively, W.D.; Lang, M.W.; Fisher, T.R.; Jordan, T.; Rice, C.P.; et al. Water quality and conservation practice effects in the Choptank River watershed. J. Soil Water Conserv. 2008, 63, 461-474. [CrossRef]

21. Duriancik, L.F.; Bucks, D.; Dobrowolski, J.P.; Drewes, T.; Eckles, S.D.; Jolley, L.; Kellogg, R.L.; Lund, D.; Makuch, J.R.; O'Neill, M.P.; et al. The first five years of the Conservation Effects Assessment Project. J. Soil Water Conserv. 2008, 63, 185A-188A. [CrossRef]

22. Lee, S.; Yeo, I.-Y.; Sadeghi, A.M.; Hively, D.W.; McCarty, G.; Lang, M. Impacts of Watershed Characteristics and Crop Rotations on Winter Cover Crop Nitrate Uptake Capacity within Agricultural Watersheds in the Chesapeake Bay Region. PLoS ONE 2016, 11, e0157637. [CrossRef] [PubMed]

23. Sharifi, A.; Lang, M.W.; McCarty, G.W.; Sadeghi, A.M.; Lee, S.; Yen, H.; Rabenhorst, M.C.; Jeong, J.; Yeo, I.Y. Improving model prediction reliability through enhanced representation of wetland soil processes and constrained model auto calibration-A paired watershed study. J. Hydrol. 2016, 541, 1088-1103. [CrossRef]

24. Arias, R.; Rodríguez-Blanco, M.L.; Taboada-Castro, M.M.; Nunes, J.P.; Keizer, J.J.; Taboada-Castro, M.T. Water resources response to changes in temperature, rainfall and $\mathrm{CO}_{2}$ concentration: A first approach in NW Spain. Water 2014, 6, 3049-3067. [CrossRef]

25. Flecher, C.; Naveau, P.; Allard, D.; Brisson, N. A stochastic daily weather generator for skewed data. Water Resour. Res. 2010, 46. [CrossRef]

26. Runkel, R.L.; Crawford, C.G.; Cohn, T.A. Load Estimator (LOADEST): A FORTRAN Program for Estimating Constituent Loads in Streams and Rivers; U.S. Geological Survey Paper; U.S. Geological Survey: Reston, VA, USA, 2004. 
27. Taylor, K.E.; Stouffer, R.J.; Meehl, G.A. An overview of CMIP5 and the experiment design. Bull. Am. Meteorol. Soc. 2012, 93, 485-498. [CrossRef]

28. Shrestha, R.R.; Dibike, Y.B.; Prowse, T.D. Modelling of climate-induced hydrologic changes in the Lake Winnipeg watershed. J. Great Lakes Res. 2012, 38, 83-94. [CrossRef]

29. Dlamini, N.S.; Kamal, M.R.; Soom, M.A.B.M.; Mohd, M.S.F.B.; Abdullah, A.F.B.; Hin, L.S. Modeling potential impacts of climate change on streamflow using projections of the 5 th assessment report for the Bernam River Basin, Malaysia. Water 2017, 9, 226. [CrossRef]

30. Moriasi, D.N.; Arnold, J.G.; Van Liew, M.W.; Bingner, R.L.; Harmel, R.D.; Veith, T.L. Model evaluation guidelines for systematic quantification of accuracy in watershed simulations. Trans. ASABE 2007, 50, 885-900. [CrossRef]

31. Singh, A.; Imtiyaz, M.; Isaac, R.K.; Denis, D.M. Assessing the performance and uncertainty analysis of the SWAT and RBNN models for simulation of sediment yield in the Nagwa watershed, India. Hydrol. Sci. J. 2014, 59, 351-364. [CrossRef]

32. Srinivasan, R.; Zhang, X.; Arnold, J. SWAT ungauged: Hydrological budget and crop yield predictions in the Upper Mississippi River Basin. Trans. ASABE 2010, 53, 1533-1546. [CrossRef]

33. Woznicki, S.A.; Nejadhashemi, A.P.; Parsinejad, M. Climate change and irrigation demand: Uncertainty and adaptation. J. Hydrol. Reg. Stud. 2015, 3, 247-264. [CrossRef]

34. Gitau, M.W.; Chaubey, I. Regionalization of SWAT Model Parameters for Use in Ungauged Watersheds. Water 2010, 2, 849-871. [CrossRef]

35. Seo, M.; Yen, H.; Kim, M.K.; Jeong, J. Transferability of SWAT Models between SWAT2009 and SWAT2012. J. Environ. Qual. 2014, 43, 869-880. [CrossRef] [PubMed]

36. Parajuli, P.B.; Jayakody, P.; Sassenrath, G.F.; Ouyang, Y.; Pote, J.W. Assessing the impacts of crop-rotation and tillage on crop yields and sediment yield using a modeling approach. Agric. Water Manag. 2013, 119, $32-42$. [CrossRef]

37. Jha, M.; Arnold, J.G.; Gassman, P.W.; Giorgi, F.; Gu, R.R. Climate change sensitivity assessment on upper Mississippi river basin streamflows using SWAT. J. Am. Water Resour. Assoc. 2006, 42, 997-1015. [CrossRef]

38. Mengistu, D.T.; Sorteberg, A. Sensitivity of SWAT simulated streamflow to climatic changes within the Eastern Nile River basin. Hydrol. Earth Syst. Sci. 2012, 16, 391-407. [CrossRef]

39. Wu, Y.; Liu, S.; Gallant, A.L. Predicting impacts of increased $\mathrm{CO}_{2}$ and climate change on the water cycle and water quality in the semiarid James River Basin of the Midwestern USA. Sci. Total Environ. 2012, 430, 150-160. [CrossRef] [PubMed]

40. Praskievicz, S. Impacts of Projected Climate Changes on Streamflow and Sediment Transport for Three Snowmelt-Dominated Rivers in the Interior Pacific Northwest. River Res. Appl. 2016, 32, 4-17. [CrossRef]

41. Lee, S.; Yeo, I.Y.; Sadeghi, A.M.; McCarty, G.; Hively, D.W.; Lang, M.; Sharifi, A. Comparative analyses of hydrological responses of two adjacent watersheds to climate variability and change scenarios using SWAT model. Hydrol. Earth Syst. Sci. 2018, 22, 689-708. [CrossRef]

42. Suddick, E.C.; Whitney, P.; Townsend, A.R.; Davidson, E.A. The role of nitrogen in climate change and the impacts of nitrogen-climate interactions in the United States: Foreword to thematic issue. Biogeochemistry 2013, 114, 1-10. [CrossRef]

43. Döll, P.; Siebert, S. Global modeling of irrigation water requirements. Water Resour. Res. 2002, 38. [CrossRef]

44. Räty, O.; Räisänen, J.; Ylhäisi, J.S. Evaluation of delta change and bias correction methods for future daily precipitation: Intermodel cross-validation using ENSEMBLES simulations. Clim. Dyn. 2014, 42, 2287-2303. [CrossRef]

(C) 2018 by the authors. Licensee MDPI, Basel, Switzerland. This article is an open access article distributed under the terms and conditions of the Creative Commons Attribution (CC BY) license (http:/ / creativecommons.org/licenses/by/4.0/). 